\title{
Cryptococcus statzelliae sp. nov. and three novel strains of Cryptococcus victoriae, yeasts isolated from Antarctic soils
}

\author{
${ }^{1}$ School of Biological \\ Sciences, University of New \\ England, Armidale, \\ NSW 2351, Australia \\ 2 Rosenstiel School of \\ Marine and Atmospheric \\ Science, University of \\ Miami, 4600 Rickenbacker \\ Causeway, Key Biscayne, \\ FL, USA
}

\author{
Skye Thomas-Hall, ${ }^{1}$ Kenneth Watson ${ }^{1}$ and Gloria Scorzetti ${ }^{2}$ \\ Author for correspondence: Skye Thomas-Hall. Tel: +6126773 2729. Fax: +61267733267. \\ e-mail: sthomas2@metz.une.edu.au
}

\begin{abstract}
A morphological and physiological characterization of yeast strains CBS 8908, CBS 8915, CBS 8920, CBS 8925 ${ }^{\top}$ and CBS 8926, isolated from Antarctic soils, was performed. Phylogenetic analyses of the sequences of the D1/D2 regions and the adjacent internal transcribed spacer (ITS) regions of the large-subunit rDNA of these strains placed them into the Tremellales clade of the Hymenomycetes. The sequence data identified strains CBS 8908, CBS 8915 and CBS 8920 as belonging to the species Cryptococcus victoriae. Strains CBS $8925^{\top}$ and CBS 8926 were found to represent an unique clade within the Hymenomycetes, with Dioszegia crocea CBS $6714^{\top}$ being their closest phylogenetic relative. Fatty acid composition and proteome fingerprint data for these novel strains were also obtained. No sexual state was observed. A novel basidiomycetous species, Cryptococcus statzelliae, is proposed for strains CBS $8925^{\top}$ and CBS 8926.
\end{abstract}

Keywords: Cryptococcus statzelliae sp. nov., rDNA sequencing, fatty acids, PAGE, scanning electron microscopy

\section{INTRODUCTION}

A survey of yeasts in soil and snow samples from Antarctica resulted in the collection of over 500 isolates. Two morphologically similar isolates with red colonies, CBS $8925^{\mathrm{T}}$ and CBS 8926, were shown to be closely related by PAGE analysis of whole-cell proteins. Phylogenetic analyses of the D1/D2 and internal transcribed spacer (ITS) regions of the largesubunit rDNA of these strains confirmed their relatedness and showed them to represent a novel species. Based on carbon assimilation data, the absence of fermentation, positive Diazonium blue B and urease reactions, production of starch-like compounds and the lack of an inducible sexual state or the formation of ballistoconidia, these isolates were classified as be-

Published online ahead of print on 21 June 2002 as DOI 10.1099/ ijs.0.02293-0.

Abbreviation: ITS, internal transcribed spacer.

The GenBank accession numbers for the sequences of the D1/D2 domains of C. statzelliae CBS $8925^{\top}$, C. statzelliae CBS 8926, C. victoriae CBS 8920, C. victoriae CBS 8915 and C. victoriae CBS 8908 are AY029341, AY029344, AY040650, AY040652 and AY040653, respectively. The GenBank accession numbers for the ITS sequences of strains CBS 8925 ${ }^{\top}$, CBS 8926, CBS 8908, CBS 8915 and CBS 8920 are AY029342, AY029343, AY040654, AY040655 and AY040656, respectively. longing to the genus Cryptococcus (Kurtzman \& Fell, 1998). The two strains, CBS $8925^{\mathrm{T}}$ and CBS 8926, are described in this communication as Cryptococcus statzelliae sp. nov., in honour of Adele StatzellTallman, a yeast biologist at the University of Miami, FL, USA.

Three yeast isolates, CBS 8908, CBS 8915 and CBS 8920 , were shown by phylogenetic analyses of the D1/D2 and ITS regions of their large-subunit rDNA to be closely related to the type strain of Cryptococcus victoriae, CBS $8685^{\mathrm{T}}$. PAGE proteome fingerprinting of these strains showed them to be very similar, thus supporting the relationship between them. On the basis of these data and the results of carbon-assimilation tests, CBS 8908, CBS 8915 and CBS 8920 are presented as variant strains of $C$. victoriae.

\section{METHODS}

Isolation techniques. The yeast strains used in this study can be found in Table 1. Soil and snow samples were collected from Vestvold Hills, Davis Base, Antarctica, in December 1997. Samples were stored at $-10{ }^{\circ} \mathrm{C}$ in quarantine and screened for yeasts in April 1998. Soil samples (0.1 g) were added to YEP (yeast extract/peptone/2\% glucose) broth containing $250 \mu \mathrm{g}$ streptomycin $\mathrm{ml}^{-1}$ and $500 \mu \mathrm{g}$ ampi- 
Table 1. Yeast strains examined in this study

All strains were isolated from Antarctica, except for D. crocea. Lichen Valley, $68^{\circ} 29^{\prime} \mathrm{S} 78^{\circ} 25^{\prime} \mathrm{E}$; Echo Lake, $68^{\circ} 31^{\prime} \mathrm{S} 78^{\circ} 16^{\prime} \mathrm{E}$.

\begin{tabular}{|c|c|c|c|c|c|c|c|}
\hline \multirow[t]{2}{*}{ Details } & \multirow{2}{*}{$\begin{array}{c}\text { D. crocea } \\
\text { CBS } 6714^{\mathrm{T}}\end{array}$} & \multirow{2}{*}{$\begin{array}{c}\text { C. statzelliae } \\
\text { CBS } 8925^{\mathrm{T}}\end{array}$} & \multirow{2}{*}{$\begin{array}{c}\text { C. statzelliae } \\
\text { CBS } 8926\end{array}$} & \multicolumn{4}{|c|}{ C. victoriae } \\
\hline & & & & CBS 8685 ${ }^{\mathrm{T}}$ & CBS 8908 & CBS 8915 & CBS 8920 \\
\hline Substrate & Strawberry & Soil & Soil & Soil & Soil & Soil & Soil, lichen \\
\hline Source/isolated from & UK & Lichen Valley & Echo Lake & Victoria Land & Lichen Valley & Lichen Valley & Lichen Valley \\
\hline ITS accession no. & - & AY029342 & AY029343 & - & AY040654 & AY040655 & AY040656 \\
\hline
\end{tabular}

cillin $\mathrm{ml}^{-1}$; the samples were incubated at $10^{\circ} \mathrm{C}$. Serial dilutions of the broth cultures were inoculated onto YEP/ streptomycin/ampicillin agar plates at 0,5 and 10 days postinoculation, and the plates were incubated at $10^{\circ} \mathrm{C}$ until colony growth was visible. Yeast isolates were then streaked onto YEP agar plates.

Morphology. Cell size and morphology were determined by scanning electron microscopy (JEOL model JSM'5800LV, accelerating voltage $15 \mathrm{kV}$ ) using an improved fixation procedure for yeasts (Hanschke \& Schauer, 1996).

Physiological tests. Physiological tests were performed in duplicate according to the protocols described by Yarrow (1998).

Protein extraction. Cells in the exponential growth phase (YEP broth at $15^{\circ} \mathrm{C}$ for 3-5 days) were pelleted by centrifugation at $2000 \mathrm{~g}$ for $5 \mathrm{~min}$, washed once with distilled water $\left(\mathrm{dH}_{2} \mathrm{O}\right)$ and then centrifuged. To the pellet was added $150 \mu \mathrm{l}$ ice-cold lysis buffer $(0 \cdot 1 \%$ Triton X-100, $100 \mathrm{mM}$ $\mathrm{KCl}, 8 \mathrm{mM} \mathrm{MgCl}, 150 \mathrm{mM} \mathrm{NaCl}, 20 \mathrm{mM}$ Tris$/ \mathrm{HCl}, \mathrm{pH}$ $7 \cdot 4,1 \mathrm{mM}$ PMSF) and an equal volume of $0.5 \mathrm{~mm}$ glass beads. Samples were vigorously vortexed for $30 \mathrm{~s}$, followed by $30 \mathrm{~s}$ on ice; this procedure was repeated eight times. The lysed cells were centrifuged ( $1500 \mathrm{~g}$ for $5 \mathrm{~min}$ ) and the supernatant was taken for protein analysis. Protein concentrations were determined by a modified Bradford Coomassie method (Pierce). Equal volumes of $3 \times$ gel loading buffer (150 mM Tris/HCl, pH 6.8, $300 \mathrm{mM}$ DTT, 6\% SDS, $3 \%$ bromophenol blue, $30 \%, \mathrm{v} / \mathrm{v}$, glycerol) were added to the samples and they were boiled for $3 \mathrm{~min}$ to denature the proteins.

PAGE. PAGE was performed according to Laemmli (1970). Proteins $(10 \mu \mathrm{g})$ were loaded into each well on an SDS resolving acrylamide gel with a $4 \%$ stacking gel. Gels were run at $30 \mathrm{~mA}, 400 \mathrm{~V}$ at $10{ }^{\circ} \mathrm{C}$ for about $4 \mathrm{~h}$, until the dye had migrated to the bottom of the gel. Gels were silver-stained (Bio-Rad silver stain kit) and dried; the images were scanned for later analysis.

PCR products. A loopful of yeast cells from a pure culture was washed with $\mathrm{dH}_{2} \mathrm{O}$ and then resuspended in $1 \mathrm{ml} \mathrm{dH_{2 }} \mathrm{O}$. Amplicons were obtained by using $5 \mu$ l of this cell suspension and the Finnzyme system (Geneworks) [5 $\mu 110 \times$ buffer 511 , $1 \mu \mathrm{l}$ dNTP mix, $1 \mu$ l Dynazyme II (polymerase), $25 \mathrm{pmol}$ forward primer NS7 (5'-GAGGCAATAACAGGTCTGTGATGC-3') and 25 pmol reverse primer LR6 (5'-CGCCAGTTCTGCTTACC-3') in a final volume of $50 \mu 1$ made up with $\mathrm{dH}_{2} \mathrm{O}$ ]. The PCR reaction steps were as follows: initial denaturation at $94^{\circ} \mathrm{C}$ for $1 \mathrm{~min}, 30$ cycles at $94^{\circ} \mathrm{C}$ for $1 \mathrm{~min}$, $55^{\circ} \mathrm{C}$ for $1 \mathrm{~min}$ and $72{ }^{\circ} \mathrm{C}$ for $1 \mathrm{~min}$, with a final step at $70^{\circ} \mathrm{C}$ for $8 \mathrm{~min}$. The amplification of products of approximately $2 \cdot 2 \mathrm{~kb}$ in size was confirmed by agarose gel electrophoresis; the PCR products were purified using the QIAquick purification kit (Qiagen).

Sequencing. The D1/D2 region of the $26 \mathrm{~S}$ rDNA was amplified by cycle sequencing using forward primer F63 (5'GCATATCAATAAGCGGAGGAAAAG-3') and reverse primer LR3 (5'-GGTCCGTGTTTCAAGACGG-3'); the ITS regions were analysed using forward primer ITS1 (5'TCCGTAGGTGAACCTGCGG-3') and reverse primer ITS4 (5'-TCCTCCGCTTATTGATATGC-3') (Fell et al., 2000). The sequences were obtained with a Li-Cor automated sequencer using a standard protocol. The sequences were analysed and corrected using Li-Cor ALIGNIR, and aligned to the sequences of their closest phylogenetic relatives using MEGALIGN (DNAStar). Phylogenetic analyses were computed with PAUP 4.0 using parsimony analysis (heuristic search, random stepwise additions).

Lipid extraction and fatty acid analysis. Cells for fatty acid analysis were grown in YEP broth and then washed twice with $\mathrm{dH}_{2} \mathrm{O}$. Fatty acid extractions were performed according to Rule (1996). Samples were analysed as described by Swan \& Watson (1997).

\section{RESULTS AND DISCUSSION \\ PAGE analysis of whole-cell proteins}

Proteome fingerprinting by PAGE was used as a rapid, initial screening step for the preliminary characterization of the Antarctic yeasts isolated as part of our ongoing studies (S. Thomas-Hall \& K. Watson, unpublished results). Protein profiles of strains CBS $8925^{\mathrm{T}}$ and CBS 8926 and of Dioszegia crocea CBS $6714^{\mathrm{T}}$ were obtained by PAGE for comparative proteome fingerprinting (Fig. 1). Strains CBS $8925^{\mathrm{T}}$ and CBS 8926 were shown to have essentially identical proteome fingerprints, thus supporting their relatedness. By contrast, the proteome fingerprint of $D$. crocea CBS $6714^{\mathrm{T}}$, although sharing some similar banding patterns with strains $\mathrm{CBS} 8925^{\mathrm{T}}$ and $\mathrm{CBS}$ 8926, was different from those of the novel strains, and the majority of its protein bands did not align with those of the novel strains. This phenotypic difference supports the classification of strains CBS $8925^{\mathrm{T}}$ and CBS 8926 as a novel species that is taxonomically distinct from $D$. crocea. 


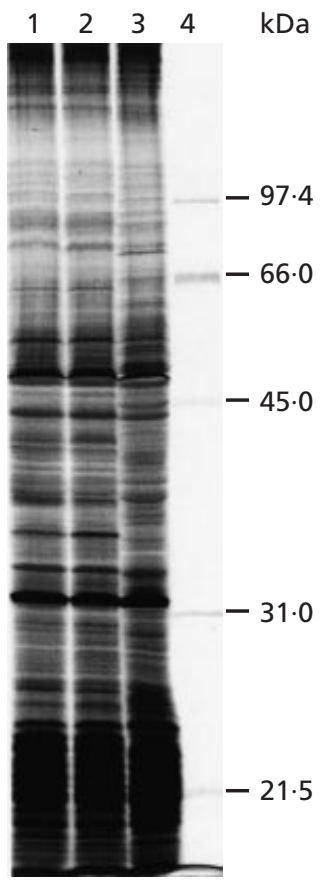

Fig. 1. PAGE ( $12 \cdot 5 \%$ acrylamide) analysis of whole-cell-protein extracts. Lanes: 1 , protein extract of strain CBS $8925^{\top} ; 2$, protein extract of strain CBS 8926; 3, protein extract of $D$. crocea CBS $6714^{\top} ; 4$, low-molecular-mass markers.

\section{Fatty acid analysis}

Cells were grown at $15^{\circ} \mathrm{C}$ to stationary phase and their fatty acid profiles determined by GC. The total fatty acids of the novel strains comprised $\sim 50 \%$ oleic acid $\left(\mathrm{C}_{18: 1}\right), \sim 30 \%$ linoleic acid $\left(\mathrm{C}_{18: 2}\right), \sim 7 \%$ linolenic acid $\left(\mathrm{C}_{18: 3}\right)$ and $\sim 10 \%$ palmitic acid $\left(\mathrm{C}_{16: 0}\right)$. These results were consistent with previous findings for the fatty acid compositions of Antarctic yeasts (Watson, 1987). In contrast, palmitoleic acid $\left(\mathrm{C}_{16: 1}\right)$, a major fatty acid in Saccharomyces cerevisiae, was found only in trace quantities $(<0.5 \%)$, a characteristic of members of the genus Cryptococcus (Ratledge \& Evans, 1989).

\section{Sequence analysis}

Phylogenetic analyses based on the D1/D2 region of the large-subunit rDNA sequences of the novel strains indicated that strains CBS $8925^{\mathrm{T}}$ and CBS 8926 belonged to the Tremellales clade of the hymenomycetous yeasts (Fell et al., 2000). The closest phylogenetic relative of these two strains was $D$. crocea, which differed by $10 \mathrm{nt}$ from strain CBS $8925^{\mathrm{T}}$ and by $12 \mathrm{nt}$ from strain CBS 8926 (Fig. 2). The nucleotide sequences from the ITS1-5.8S-ITS2 regions of strains CBS $8925^{\mathrm{T}}$ and CBS 8926 were identical. Utilizing the same strains as shown in Fig. 2, phylogenetic analysis of the ITS1-5.8S-ITS2 sequences (data not shown) confirmed the relationships observed in D1/D2 phylogenetic tree (Fig. 2). The sequence data supported the

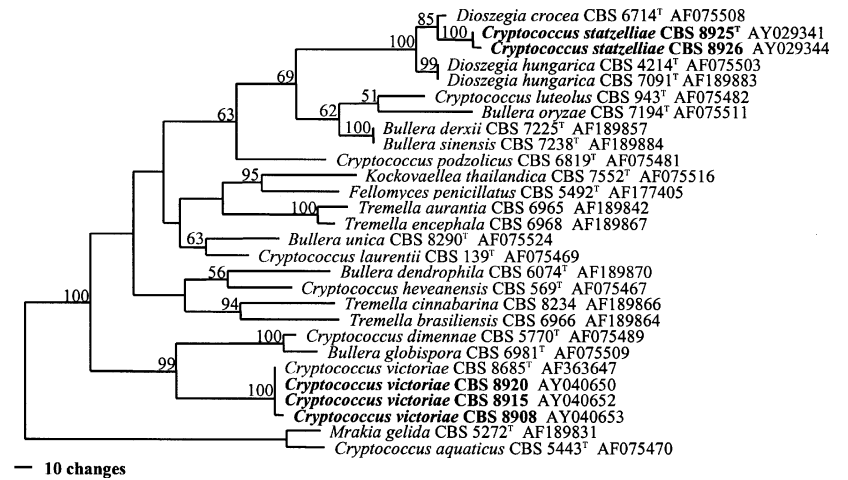

Fig. 2. Phylogenetic analysis of the D1/D2 region of the largesubunit rDNA. Bootstrap values are expressed as a percentage of 100 full heuristic bootstrap replications. The sequences of Mrakia gelida and Cryptococcus aquaticus were used as outgroups.

classification of strains CBS $8925^{\mathrm{T}}$ and CBS 8926 as a taxonomically distinct species within the Dioszegia clade, as shown in Fig. 2. Recently, it has been reported that the defining characteristic of members of the Dioszegia clade is the secondary structure of the $18 \mathrm{~S}$ rDNA (Takashima, Deak \& Nakase, 2001); thus, further analyses on the 18S rDNA of the strains used in this study would be informative.

\section{Sexual state}

Numerous experimental conditions were tested in an attempt to induce a sexual state in strains CBS $8925^{\mathrm{T}}$ and CBS 8926. These tests included the plating of each strain and a mixture of both strains onto YEP agar, corn meal agar, malt agar, carbon base agar and nitrogen base agar, and their inoculation into YEP broth and distilled water. The plates and broth were incubated at 6 and $15{ }^{\circ} \mathrm{C}$. Plates and broths were examined at 1, 3, 6 and 9 months post-inoculation; although pseudohyphae were noted infrequently, no sexual structures were observed for the two strains.

\section{Ballistoconidia formation}

The inverted-plate method of Phaff \& do CarmoSousa (1962) was employed to determine whether ballistoconidia were formed by strains CBS $8925^{\mathrm{T}}$ and CBS 8926; corn meal agar plates inverted over YEP plates at 6 and $15^{\circ} \mathrm{C}$ were used. D. crocea was used as the positive control; this strain formed a mirror image of the streaks (indicating the presence of ballistoconidia) within 4 weeks incubation at both temperatures tested. Neither of the novel strains nor a mixed culture of the two produced ballistospores after up to 9 months incubation.

Based on the phenotypic and molecular data presented above, it is proposed that strains CBS $8925^{\mathrm{T}}$ and CBS 8926 be classified a novel species within the genus Cryptococcus, Cryptococcus statzelliae. 


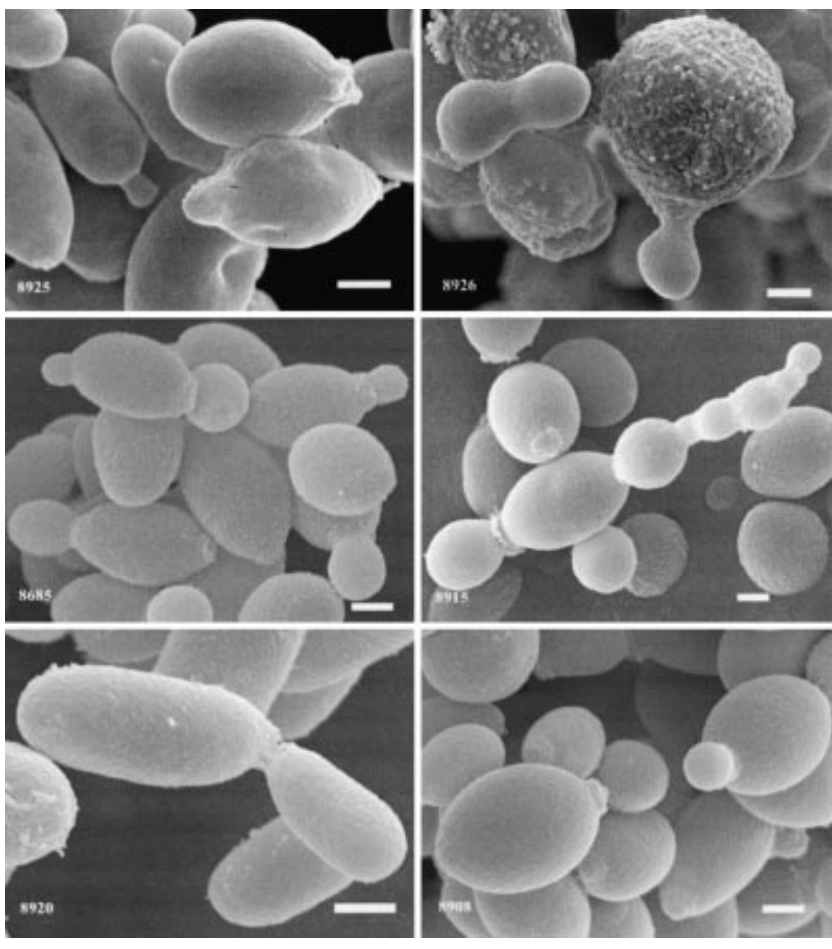

Fig. 3. Scanning electron micrographs of strains CBS $8925^{\top}$ and CBS 8926 and of C. victoriae CBS $8685^{\top}$, CBS 8908, CBS 8915 and CBS 8920 showing budding cells and bud scars. Bars, $1 \mu \mathrm{m}$.

\section{Latin diagnosis of Cryptococcus statzelliae Thomas- Hall, Watson et Scorzetti sp. nov.}

Haec species e Lichen Valley $\left(68^{\circ} 29^{\prime} \mathrm{S} 78^{\circ} 25^{\prime} \mathrm{E}\right)$ et Echo Lake (68 $\left.31^{\prime} \mathrm{S} 78^{\circ} 16^{\prime} \mathrm{E}\right)$, Vestvold Hills, Davis Base, Antarctica, separata est. In YEP agaro post dies $3\left(15^{\circ} \mathrm{C}\right)$, cellulae globosae vel ovoidae capsulatae, singulae vel binae sunt $(2-3 \times 3-4 \mu \mathrm{m})$; breves pseudohyphae $(10-20 \mu \mathrm{m})$ post dies formatae sunt. Flosculi (plerumque polares) quos iungit breve tuber, cicatrices linquunt. In YEP agaro species fert convexas rotundas, rubentes colonias, quae 1-2 mm diametron plerumque habent. Status sexualis non apparet. Assimilat: glucosum, galactosum, sucrosum, cellobiosum, trehalosum, raffinosum, D-xylosum, L-arabinosum, $\mathrm{N}$-acetyl-D-glucosaminum, galacticolum, D-mannitolum, D-glucitol, Dgluconatum, DL-lactatum, D-glucuronatum, $10 \% \mathrm{NaCl}$ $5 \%$ glucosum. Exigue respondent: maltosum, melibiosum, melezitosum, D-arabinosum, D-ribosum, D-glucosaminum, ribitolum, salicinum, succinatum. Non assimilantur: L-sorbosum, lactosum, inulinum, amylum, solubile, methanolum, ethanolum, glycerolum, erythritolum, methyl $\alpha$-D-glucosidium, citratum, inositolum, hexadecanum, nitratum. Ad crescentiam vitaminae externae necessariae sunt. Amyli instar composita creantur. Fermentatio nulla. Incrementum in $25^{\circ} \mathrm{C}$ non respondet, maxima incrementi temperatio est $22^{\circ} \mathrm{C}$, optime crescit in $15-18{ }^{\circ} \mathrm{C}$. In collectione zymotica Centraalbureau voor Schimmelcultures, Uppsalalaan 8, 3584 CT Trajectum ad Rhenum, Neerlandia, CBS
$8925^{\mathrm{T}}$ est Cryptococcus statzelliae, et CBS 8926 est Cryptococcus statzelliae.

\section{Description of Cryptococcus statzelliae Thomas-Hall, Watson \& Scorzetti sp. nov.}

Cryptococcus statzelliae (stat.zell'i.ae. N.L. gen. fem. n. statzelliae in honour of Adele Statzell-Tallman).

Isolated from soil from Lichen Valley $\left(68^{\circ} 29^{\prime} \mathrm{S}\right.$ $\left.78^{\circ} 25^{\prime} \mathrm{E}\right)$ and Echo Lake $\left(68^{\circ} 31^{\prime} \mathrm{S} 78^{\circ} 16^{\prime} \mathrm{E}\right)$, Vestvold Hills, Davis Base, Antarctica. After 3 days growth at $15{ }^{\circ} \mathrm{C}$ in YEP broth, the cells are sphaeroidal to ovoid, occur singly or in parent-bud pairs and measure 2-3 $2-4 \mu \mathrm{m}$; short pseudohyphae $(10-20 \mu \mathrm{m})$ are formed infrequently after 4 weeks incubation at $6^{\circ} \mathrm{C}$. Budding is polar, a short protuberance connects budding cells, leaving raised bud scars (Fig. 3). Grows on YEP agar giving rise to convex, circular, shiny, orange/red colonies that are generally $1-2 \mathrm{~mm}$ in diameter. No sexual state is observed. Carbon compounds assimilated: glucose, galactose, sucrose, cellobiose, trehalose, raffinose, Dxylose, L-arabinose, L-rhamnose, $\mathrm{N}$-acetyl-D-glucosamine, galactitol, D-mannitol, D-glucitol, D-gluconate, DL-lactate, D-glucuronate and $10 \% \mathrm{NaCl} 5 \%$ glucose. Growth response is weak for maltose, melibiose, melezitose, D-arabinose, D-ribose, D-glucosamine, ribitol, salicin and succinate. Compounds not assimilated: L-sorbose lactose, inulin, soluble starch, methanol, ethanol, glycerol, erythritol, methyl $\alpha$-D-glucoside, citrate, inositol, hexadecane, and vitamin-free, biotin-free and thiamin-free media. Nitrate assimilation is negative. Starch-like compounds are formed. Diazonium blue B- and urease-positive. Growth on $50 \%(\mathrm{w} / \mathrm{w})$ glucose/yeast extract agar is negative. Gelatin liquefaction is negative. Fermentation is absent. Growth at $25^{\circ} \mathrm{C}$ is negative, maximum growth temperature is $22^{\circ} \mathrm{C}$, optimal growth temperature is between 15 and $18^{\circ} \mathrm{C}$. Strains CBS $8925^{\mathrm{T}}$ and CBS 8926 are available from the collection of the Yeast Division of the Centraalbureau voor Schimmelcultures, Uppsalalaan 8, 3584 CT Utrecht, The Netherlands.

\section{Three novel strains of C. victoriae Montes et al. (1999), CBS 8908, CBS 8915 and CBS 8920}

Morphology. C. victoriae CBS $8685^{\mathrm{T}}$ gives rise to convex, smooth, round, light-pink, butyrous colonies; cell size is $3-5 \times 2-3 \mu \mathrm{m}$; budding is polar (Fig. 3). Strain CBS 8908 gives rise to convex, smooth, round, peach (yellow/orange), butyrous colonies; cell size is $3-5 \times 2-3 \mu \mathrm{m}$; budding is polar (Fig. 3). Strain CBS 8915 gives rise to umbonate, irregular, pink, pasty colonies; cell size is $3-5 \times 2-3 \mu \mathrm{m}$; budding is bipolar (Fig. 3); cells aggregate into clusters and form a granular sediment in YEP broth after 1 week incubation at $15^{\circ} \mathrm{C}$. Strain CBS 8920 gives rise to convex, smooth, round, apricot (pink/orange), butyrous colonies; cell size is generally $3-5 \times 2-3 \mu \mathrm{m}$, 
Table 2. Assimilation tests that varied among the strains of $C$. victoriae studied here

Strains: 1, C. victoriae $8685^{\mathrm{T}} ; 2$, C. victoriae 8908 ; 3, C. victoriae $8915 ; 4$, C. victoriae $8920 .+$, Positive reaction; - , negative reaction; w, weak reaction; s, slow reaction.

\begin{tabular}{|lcccc|}
\hline Growth test & $\mathbf{1}$ & $\mathbf{2}$ & $\mathbf{3}$ & $\mathbf{4}$ \\
\hline L-Sorbose & - & $\mathrm{w}$ & - & - \\
Cellobiose & + & + & + & $\mathrm{w}$ \\
Lactose & + & + & + & - \\
Soluble starch & $\mathrm{w}$ & $\mathrm{s} / \mathrm{w}$ & - & - \\
L-Arabinose & + & $\mathrm{w}$ & + & + \\
L-Rhamnose & + & $\mathrm{w}$ & + & + \\
D-Glucosamine & $\mathrm{w}$ & $\mathrm{w}$ & + & $\mathrm{W}$ \\
Galactitol & + & + & $\mathrm{w}$ & $\mathrm{W}$ \\
Methyl $\alpha$-D-glucoside & + & + & + & $\mathrm{W}$ \\
Succinate & + & $\mathrm{w}$ & $\mathrm{w}$ & + \\
Citrate & + & $\mathrm{w}$ & $\mathrm{W}$ & - \\
Inositol & + & $\mathrm{w}$ & $\mathrm{w}$ & $\mathrm{w}$ \\
Vitamin-free medium & + & $\mathrm{w}$ & + & $\mathrm{w}$ \\
D-Glucuronate & + & $\mathrm{w}$ & + & + \\
$10 \%$ NaCl $5 \%$ glucose & $\mathrm{w}$ & $\mathrm{w}$ & + & $\mathrm{w}$ \\
$50 \%$ (w/w) glucose/yeast & - & - & $\mathrm{w} /-$ & \\
extract agar & & & & \\
\hline
\end{tabular}

with large cells $(10 \times 4 \mu \mathrm{m})$ formed occasionally; budding is polar (Fig. 3).

Phenotypic characterization. Table 2 displays the carbon assimilation results that varied between the four $C$. victoriae strains tested. These tests were performed in three separate experiments, to confirm the results. Carbon compounds assimilated by the four $C$. victoriae strains: glucose, galactose, sucrose, trehalose, melibiose, raffinose, melezitose, inulin, D-xylose, D-arabinose, D-ribose, $N$-acetyl-D-glucosamine, glycerol, erythritol, ribitol, D-mannitol, D-glucitol and D-gluconate. Carbon compounds not assimilated: methanol, ethanol, soluble starch, DL-lactate and hexadecane. Nitrate assimilation, growth in biotin-free media and the urease test are all positive. Starch compounds are not formed, gelatin is not liquefied and growth at $25^{\circ} \mathrm{C}$ is negative.

PAGE of whole-cell proteins. The protein profiles of $C$. victoriae CBS $8658^{\mathrm{T}}$, CBS 8908 , CBS 8915 and CBS 8920 (Fig. 4) showed an overall similarity, with only a few unique bands for each of the strains. The similar protein fingerprints obtained indicated that these strains were closely related.

Sequence analysis. Phylogenetic analysis of the D1/ D2 sequences (Fig. 2) of the four strains showed that C. victoriae CBS $8658^{\mathrm{T}}$, CBS 8915 and CBS 8920 have identical sequences, while CBS 8908 differed from these strains by $2 \mathrm{nt}$. Analysis of the ITS1-5.8SITS2 sequences showed that C. victoriae CBS $8658^{\mathrm{T}}$, CBS 8908, CBS 8915 and CBS 8920 differed from each other by $1 \mathrm{nt}$. These phylogenetic and morphological data supported the classification of CBS strains 8908, 8915 and 8920 as strains of the species $C$. victoriae.

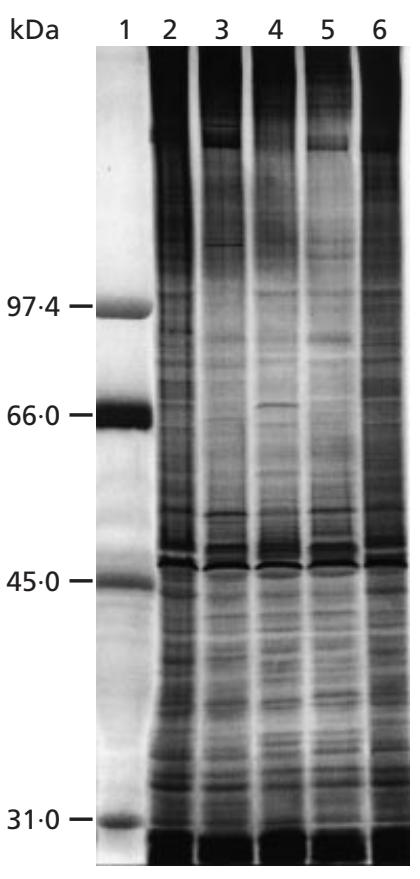

Fig. 4. PAGE ( $10 \%$ acrylamide) analysis of whole-cell-protein extracts. Lanes: 1 , low-molecular-mass markers; 2 and 6 , protein extract of $C$. victoriae CBS $8685^{\top} ; 3$, protein extract of $C$. victoriae CBS 8908; 4, protein extract of C. victoriae CBS 8920; 5 , protein extract of $C$. victoriae CBS 8915 .

\section{ACKNOWLEDGEMENTS}

This work was supported in part by the Australian Research Council (K.W.), an UNE postgraduate scholarship (S.T.H.) and the National Science Foundation, Division of Ocean 
Sciences (J.W. Fell). We thank John Bowman and Tom McMeekin of the Antarctic CRC, University of Tasmania, Hobart, Australia, for supplying soil samples and helpful discussions. Special thanks to Jack W. Fell for the use of his laboratory and database. Allan Treloar is acknowledged for the Latin translation.

\section{REFERENCES}

Fell, J. W., Boekhout, T., Fonseca, A., Scorzetti, G. \& StatzellTallman, A. (2000). Biodiversity and systematics of basidiomycetous yeasts as determined by large-subunit rDNA D1/D2 domain sequence analysis. Int J Syst Evol Microbiol 50, 1351-1371.

Hanschke, R. \& Schauer, F. (1996). Improved ultrastructural preservation of yeast cells for scanning electron microscopy. J Microsc 184, $81-87$.

Kurtzman, C. P. \& Fell, J. W. (1998). Summary of species characteristics. In The Yeasts: a Taxonomic Study, 4th edn, pp. 924-927. Edited by C. P. Kurtzman \& J. W. Fell. Amsterdam: Elsevier.

Laemmli, U. K. (1970). Cleavage of structural proteins during the assembly of the head of bacteriophage T4. Nature 227, 680-685.

Montes, M. J., Belloch, C., Galiana, M., Garcia, M. D., Andrés, C., Ferrer, S., Torres-Rodriguez, J. M. \& Guinea, J. (1999). Polyphasic taxonomy of a novel yeast isolated from Antarctic environment; description of Cryptococcus victoriae sp. nov. Syst Appl Microbiol 22, 97-105.

Phaff, H. J. \& do Carmo-Sousa, L. (1962). Four new species of yeast isolated from insect frass in bark of Tsuga heterophylla (Raf.) Sargent. Antonie van Leeuwenhoek 28, 193-207.

Ratledge, C. \& Evans, C. T. (1989). Lipids and their metabolism. In The Yeasts, vol. 3, 2nd edn, pp. 367-455. Edited by A. H. Rose \& J. S. Harrison. London: Academic Press.

Rule, D. C. (1996). Direct transesterification of total fatty acids of adipose tissue, and freeze-dried muscle and liver with boron-trifluoride in methanol. Meat Sci 46, 23-32.

Swan, T. M. \& Watson, K. (1997). Membrane fatty acid composition and membrane fluidity as parameters of stress tolerance in yeast. Can $J$ Microbiol 43, 70-77.

Takashima, M., Deak, T. \& Nakase, T. (2001). Emendation of Dioszegia with redescription of Dioszegia hungarica and two new combinations, Dioszegia aurantiaca and Dioszegia crocea. J Gen Appl Microbiol 47, 73-84.

Watson, K. (1987). Temperature relations. In The Yeasts, vol. 2, pp. 42-71. Edited by A. H. Rose \& J. S. Harrison. London: Academic Press.

Yarrow, D. (1998). Methods for the isolation, maintenance, classification and identification of yeasts. In The Yeasts: a Taxonomic Study, 4th edn, pp. 77-101. Edited by C. P. Kurtzman \& J. W. Fell. Amsterdam: Elsevier. 